\title{
Perioperative administration of probiotics: effects on immune response, anastomotic resistance and colonic mucosal trophism ${ }^{1}$
}

\author{
Uso peroperatório de probióticos: efeitos na resposta imune, resistência anastomótica \\ e trofismo da mucosa colônica
}

\author{
José Eduardo Aguilar-Nascimento ${ }^{2}$, Sávio Prado ${ }^{3}$, Geazi Zaffani ${ }^{3}$, Alberto Bicudo Salomão ${ }^{4}$, José de Souza Neves ${ }^{5}$, Diana \\ Borges Dock-Nascimento $^{6}$, Paulo Roberto Bezerra de Mello ${ }^{7}$, Thelma Suely Okay ${ }^{8}$
}

1. Department of Surgery, Medical School, Federal University of Mato Grosso (UFMT), Cuiabá, Brazil.

2. $\mathrm{MD}, \mathrm{PhD}$, Chairman and Head of Department of Surgery, Medical School, Federal University of Mato Grosso.

3. Graduate Student, , Medical School, Federal University of Mato Grosso.

4. MD, Surgeon of the Department of Surgery, Federal University of Mato Grosso.

5. MD, Master, Assistant Professor, Department of Surgery, UFMT, Brazil.

6. Master, Assistant Professor, Nutrition School, UFMT, Brazil.

7. MD, PhD, Associate Professor, Department of Pediatrics, UFMT, Brazil.

8. MD, PhD, Associate Professor, Department of Pediatrics, University of São Paulo, Brazil.

\begin{abstract}
Purpose: To investigate the effects of perioperative administration of diet containing probiotics on the immune response, anastomotic resistance, and colonic mucosal trophism in rats underwent left-sided colonic anastomosis. Methods: Sixty adults Wistar rats were randomized to two groups (A and B) with 30 animals each to receive or not a diet supplemented with probiotics (Streptococcus thermophilus e Lactobacillus helveticus) during pre- and postoperative period. They underwent laparotomy followed by left colon section and immediate anastomosis. Groups of 15 animals were killed either on the $4^{\text {th }}$ (groups A1 and B1) or $7^{\text {th }}$ PO (groups A2 and B2) days. The outcome variables were serum proteins, albumin, globulins and IgA, lenght and weight of the colon, mucosal weight, DNA content and anastomotic bursting pressure. Results: Colonic weight was greater in probiotic group compared to controls $(1,69 \pm 0,34 \mathrm{~g} v s 1,48 \pm 0,26 \mathrm{~g} ; \mathrm{p}<0.05)$. Total serum proteins and globulin were higher in probiotic animals (proteins $=7,05 \pm 0,97 \mathrm{~g} / \mathrm{dl} v s 6,57 \pm 0,66 \mathrm{~g} / \mathrm{dl}$ e globulins $=5,1 \pm 0,62 \mathrm{~g} / \mathrm{dl} v s 4,68 \pm 1,1 \mathrm{~g} / \mathrm{dl} ; \mathrm{p}<0.05$ ). Serum IgA increased from basal to post-operative days only in the probiotic group $(\mathrm{p}<0.01)$. Conclusions: Perioperative probiotics enhanced the immune response and colonic weight. Probiotics failed to increase anastomotic resistance.

Key-words: Probiotics. Wound Healing. Immunoglobulin A. Immunity, mucosal. Anastomosis, Surgical. Colon. Intestinal Mucosa. Surgery.
\end{abstract}

\section{RESUMO}

Objetivo: Investigar os efeitos da administração peroperatória de dieta acrescida de probióticos sobre a resposta imunológica, resistência anástomótica e trofismo da mucosa colônica em ratos submetidos a anastomose do cólon esquerdo. Métodos: 60 ratos Wistar adultos foram randomizados em dois grupos (A e B), cada um com 30 animais, de acordo com o uso ou não de suplementação pré e pós-operatória de probióticos (Streptococcus thermophilus e Lactobacillus helveticus). Foram submetidos a laparotomia com secção e anastomose imediata do cólon esquerdo, e sacrificados em grupos de 15 animais no $4^{\circ}$ (grupos A1 e B1) ou $7^{\circ}$ dia de pós-operatório (grupos A2 e B2). As variáveis estudadas foram concentração plasmática de proteínas totais, albumina, globulinas e IgA; peso e comprimento do cólon sem fezes, peso da mucosa, conteúdo de DNA da mucosa e pressão anastomótica de ruptura. Resultados: Observou-se aumento do peso do intestino grosso sem fezes no grupo A (probiótico) quando comparado ao controle $(1,69 \pm 0,34 \mathrm{~g}$ vs $1,48 \pm 0,26 \mathrm{~g} ; \mathrm{p}<0.05)$. Houve aumento de proteínas totais e globulinas no grupo probiótico (proteínas $=7,05 \pm 0,97 \mathrm{~g} / \mathrm{dl} v s 6,57 \pm 0,66 \mathrm{~g} / \mathrm{dl}$ e globulinas $=5,1 \pm 0,62 \mathrm{~g} / \mathrm{dl} v s 4,68 \pm 1,1 \mathrm{~g} / \mathrm{dl} ; \mathrm{p}<0.05$ ). A IgA aumentou entre os níveis basais e o pós-operatório apenas no grupo probiótico $(\mathrm{p}<0.01)$. As demais variáveis não apresentaram diferenças entre diversos grupos estudados. Conclusão: O uso peri-operatório de probióticos melhorou a resposta imunológica e o peso do cólon. Não houve diferença na resistência anastomotica.

Descritores: Probióticos. Cicatrização de feridas. Imunoglobulina A. Imunidade nas Mucosas. Anastomose Cirúrgica. Colo. Mucosa Intestinal. Cirurgia. 


\section{Introduction}

Healing and infection are issues that demand great concern by the part of surgeons to optimize post-operative results. It is widely accepted that the nutritional status is one of the most important factors of interest to predict the healing process and post-operative infections ${ }^{1}$. In this context, malnourished patients are most prone to dehiscence and post-operative infections. Pre-operative nutritional support in this subset of patient may decrease these complications $^{2,3}$. Some functional nutrients may promote benefits for surgical patients. Colonocyte substrates namely short-chain fatty acids (SCFA) ${ }^{4}$ and enterocyte preferred fuel namely glutamine ${ }^{5}$ may ameliorate mucosal trophism and diminish translocation. Probiotics currently defined as live microorganisms that may promote speciphic benefits to the host are also implicated to modulate the intraluminal envinronment and increase IgA production ${ }^{6,7,8} .9,10$. Probiotics may also increase the SCFA production and thus enhance colonic mucosal trophism and compete with other pathogenic flora ${ }^{8-10}$. There is some evidence that probiotics may increase collagen deposition and favor angiogenesis and therefore enhance the healing process. ${ }^{11,12}$ We speculate that the use of prebiotics perioperatively may enhance anastomotic healing and the immune response. This experimental study aimed at investigating the effects of the administration of probiotics during the pre- and postoperative period on both the immune response and colonic anastomotic strength.

\section{Methods}

\section{Animals}

The study was performed at the Experimental Laboratory of the Medical School of the Federal University of Mato Grosso. The experiment followed the ethical principles of the Brazilian College of Animal Experimentation (COBEA). Sixty male Wistar rats from the Central Biotery of the Federal University of Mato Grosso (300-350g) were firstly kept for three days at the laboratory for adaptation in $12 / 12$ $\mathrm{h}$ clear/dark cycles in a constant room temperature $\left(25^{\circ} \mathrm{C}\right)$ receiving water and rat chow ad libitum. Animal were randomized to two groups: group $\mathrm{A}$ (control, $\mathrm{n}=30$ ) e grupo $\mathrm{B}$ (probiotics, $\mathrm{n}=30$ ). Both groups were divided in two subgroups of 15 animals each (A1, A2, B1, and B2).

\section{Diets}

All diets were isocaloric and isonitrogeneous. Animals of group control received $25 \mathrm{~g}$ of rat chow (AIN-93 ${ }^{13}$ ) daily whereas animals of group probiotics received $21 \mathrm{~g}$ of the same diet plus $4 \mathrm{~g}$ of reconstituted milk containing probiotics. Daily consumption was registered. Ao final de cada período de 24 horas a dieta consumida foi quantificada. Each gram of the milk contained $10^{6}$ ufc of Streptococcus thermophilus and Lactobacillus helveticus (NAN 2, Nestlé, Brasil).

\section{Experiment}

After five days receiving either one or other diet, the rats were submitted to $12 \mathrm{~h}$ fasting followed by median $4 \mathrm{~cm}$ laparotomy under inhalatory anesthesia with etilic ether. The left colon was identified and in a point $2 \mathrm{~cm}$ above the peritoneal reflexion a total transversal colotomy was performed followed by immediate one layer interrupted anastomosis using 6-0 nylon. Blood samples collected at posterior cava vein were sent to $\operatorname{IgA}$, total protein, albumin and globulin assays. IgA was assayed according to the method described by Mello ${ }^{14}$. The abdominal wall was closed in two layers with 4-0 nylon. The animals returned to their cages and the same diet was resumed $12 \mathrm{~h}$ after the end of operation. Groups A1 and B1 were operated on the $4^{\text {th }} \mathrm{PO}$ day and groups A2 and B2 on the $7^{\text {th }}$ PO day to blood collection as described and then killed with an overdose of inhalatory ether. IgA assay was performed only in subgroups killed on the $7^{\text {th }}$ PO day (A2 and B2). The colon was ressected and the segment containing the anastomosis was tested for anastomotic strenght. The rest of the colon was opened, cleaned and weighted. The mucosa was striped out, frozen and sent for DNA content assay which was done using the method described by Gyles e Myers ${ }^{15}$. Bursting pressure was done at the anastomotic region using the method described by Caporossi ${ }^{16}$. Data was analyzed by the Kolmogorov-Smirnov and Levene tests to assure normality and homogeneity. Within-group analysis was done with paired T test. Two-way Anova was used to compare groups and sub-groups. Results were expressed as mean and standard deviation. A $5 \%$ level $(\mathrm{p}<0.05)$ was established as the level of significance.

\section{Results}

There was no significant difference between the groups and sub-groups with respect to anastomotic strength (bursting pressure test), length of the colon, mucosal weight and DNA content of the mucosa. The colon of the probiotic group was heavier than controls $(1,69 \pm 0,34 \mathrm{~g}$ vs $1,48 \pm 0,26 \mathrm{~g}$; $\mathrm{p}<0.05$ ) (figure 1). Both total serum proteins $(7,05 \pm 0,97 \mathrm{~g} / \mathrm{dl}$ vs $6,57 \pm 0,66 \mathrm{~g} / \mathrm{dl} ; \mathrm{p}<0.05)$ and globulins $(5,1 \pm 0,62 \mathrm{~g} / \mathrm{dl}$ vs $4,68 \pm 1,1 \mathrm{~g} / \mathrm{dl} ; \mathrm{p}<0.05)$ were higher in probiotics group at the preoperative period when compared with control group (figure 2).

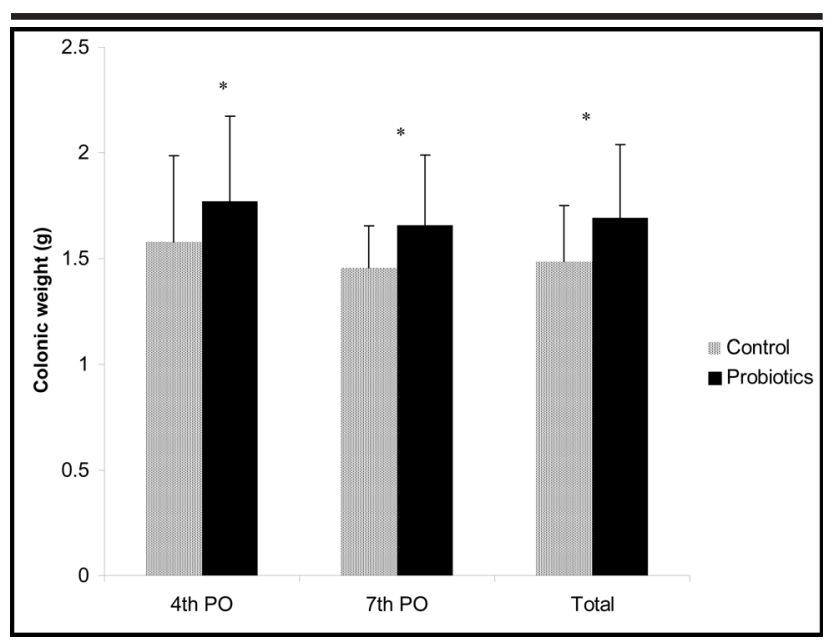

FIGURE 1 - Colonic weight without feces in the two groups. Data are mean and SD. ${ }^{*} \mathrm{p}<0,05$ vs control group. 
Serum IgA was similar between groups pre-operatively. However, the increase of serum IgA was only significant in rats that received diet containing probiotics (figure 3 ).

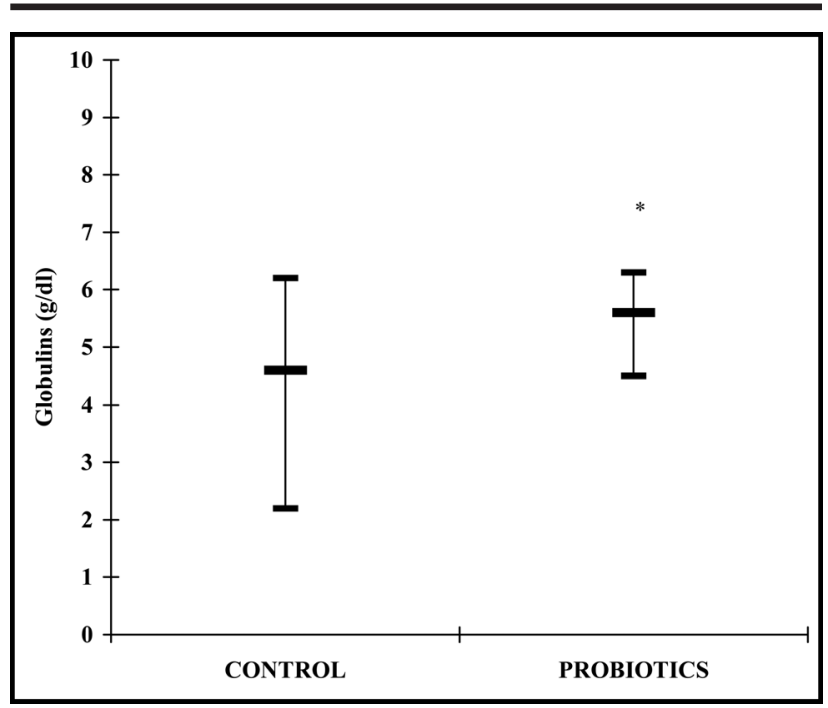

FIGURE 2 - Serum globulins at the pre-operative period in the two groups. ${ }^{*} \mathrm{p}<0,05$ vs controls.

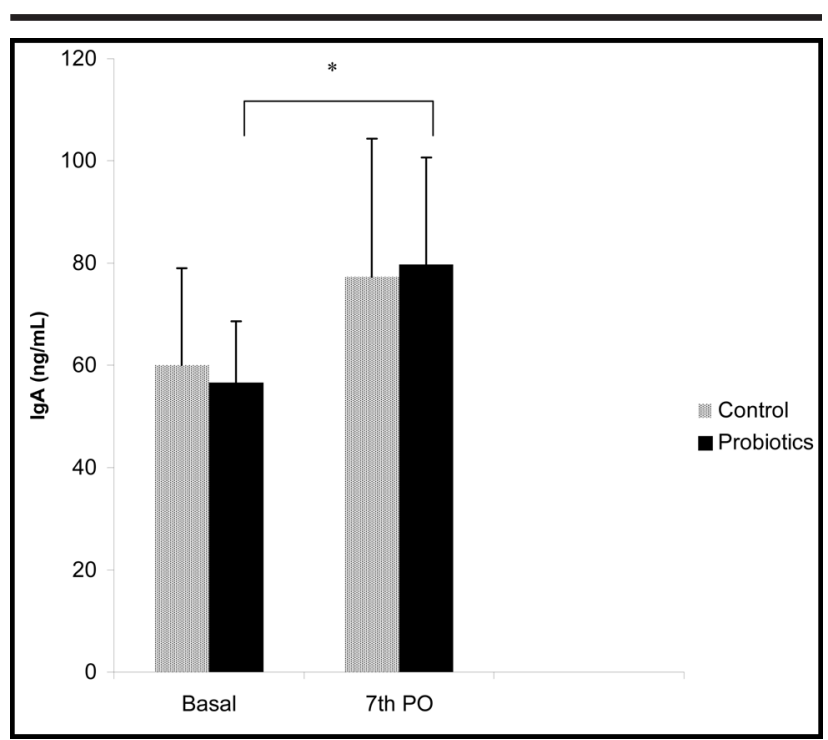

FIGURE 3 - Serum IgA in basal conditions and at the 7 th $P O$ day in the two groups. ${ }^{*} \mathrm{p}<0,05$ basal vs $7^{\circ} \mathrm{PO}$ in probiotic group.

\section{Discussion}

The overall results have shown that probiotics failed to assure an increase of the DNA content on the colonic mucosa. This result was in concordance with the similar mucosal weight seen in the experiment. The only evidence of colonic trophism favoring probiotic group was the colonic weight. This suggests an extra-mucosal trophic effect on the colonic wall that deserve further studies. Other previous study in a model of malnutrition has shown benefits of probiotics in enhancing mucosal trophism ${ }^{17}$. Probiotics may increase the production of SCFA which are directly trophic to the colonic mucosa ${ }^{18}$. As the animals of this study were not malnourished we speculate that probiotics may not benefit the trophism in nourished animals.
The findings of this experiment clearly showed that probiotics enhanced the immune response in the animals. Not only serum globulins were higher but serum IgA increased significantly more when probiotics were added in the diet. In fact, the beneficial effect of probiotics on the immune status was already been described ${ }^{19}$. Probiotics have been associated in other studies with an increase of serum $\operatorname{IgA}^{2021}$. Furthermore, oral administration of live probiotics can also differentially modulate dendritic cells resulting in an increased production of IL-10 and regulatory T cells. Thus, both innate and adaptive immune responses can be modulated by probiotic bacteria ${ }^{22}$.This findings are relevant and suggest that the use of probiotics perioperatively may benefit the patients undergoing surgery. Our findings showed that anastomotic resistance was not influenced by a diet containing probiotics. This result was in agreement with the reported by Magiante $^{2323}$. In this study the authors have shown that the healing of anastomosis was only enhanced when fibers were added in rats receiving probiotics. Probiotics alone similarly as in this present study failed to confer anastomotic resistance. The effect of symbiotic therefore should be tested in further investigation.

\section{Conclusion}

Probiotic supplementation failed to assure both mucosal trophism and anastomotic strenght after colonic anastomosis. However, the use of probiotics perioperatively enhances the immune response in rats submitted to colonic anastomosis.

\section{References}

1. Waitzberg DL, Cordeiro AC, Faintuch J. Estado nutricional no pré e pós-operatório imediato em doentes com afecções digestivas. Rev Paul Med. 1983; 101:7-13.

2. Aguilar-Nascimento JE, Goelzer J. Early feeding after intestinal anastomoses: risks or benefits? Rev Assoc Med Bras. 2002; 48:348-52.

3. Lewis SJ, Egger M, Sylvester PA, Thomas S. Early enteral feeding versus "nil by mouth" after gastrointestinal surgery: systematic review and meta-analysis of controlled trials. BMJ. 2001; 323:773-6.

4. Aguilar-Nascimento JE, Mothie RT, Man W, Willianson RCN. Enhanced intraanastomotic healing by operative lavage with nutrient solution in experimental leftsided colonic obstruction. Br J Surg. 1995; 82:461-4.

5. Souba, W.W., Herskowitz, K., Austgen, T.R., Chen, M.K., Salloum, R.M. Glutamine nutrition: theoretical considerations and therapeutic impact. JPEN J. Parenter. Enteral. Nutr1990; 14: 237-41.

6. Steidler L. Microbiological and immunological strategies for treatment of inflammatory bowel disease. Microb Infect. 2001; 3:1157-66.

7. Chiang BL, Sheih YH, Wang LH, Liao CK, GILL HS. Enhancing immuinity by dietary consumption of a probiotic latic acid bacterium (Bifidobacterium lactis HN019): optimization and definition of cellular immune responses. Eur J Clin Nutr. 2000;54:849-55. 
8. Isolauri E, Sütas Y, Kankaanpaa P, Arvilommi H, Salminen S. Probiotics: effects on immunity. Am J Clin Nutr. 2001;73 (2 Suppl):444S-450S

9. Miettinen M, Matikeinen S, Vuopio-Varkila J, Pirhonen J, Varkila K, Kurimoto M, Julkunn I. Lactobacilli and streptococci induce interleukin-12 (IL-12), IL-18 and gamma interferon production in human peripheral blood mononuclear cells. Infect Immunol. 1999; 66:6058-62.

10. Hessle, C.; Hanson, L.A.; Wold, A.E. - Lactobacilli from human gastrointestinal mucosa are strong stimulators of IL-12 production. Clin. Exp. Immunol. 1999; 116:276-82.

11. Sütas Y, Soppi E, Korhonen H, Syvaoja EL, Saxelin M, Rokka T, Isolauri E. Suppression of lymphocyte proliferation in vitro by bovine caseins hydrolyzed with Lactobacillus casei GG-derived enzymes. J Allergy Clin Immunol. 1996; 98:216-24.

12. Sütas $Y$, Hurme M, Isolauri E. - Downregulation of antiCD3 antibody-induced IL-4 production by bovine caseins hydrolysed with Lactobacillus GG-derived enzymes. Scand J Immunol. 1996; 43:687-9.

13. Reeves PG, Nielsen FH, Fahey Jr GC. AIN-93 purified diets for laboratory rodents: reporte of the American Institute of nutrition ad hoc Working committee on the reformulation of the AIN-76A rodent diet. J Nutr. 1993; 123:1939-51.

14. Mello PRB. Efeito do tabagismo sobre a liberação de prolactina, produção láctea e componentes imunes do leite de ratas. Tese de Doutorado, Faculdade de Medicina da USP; 2004.

15. Gyles KW, Meyers A. An improved diphenylamine method for the estimation of desoxyribonucleic acid. Nature. 1965; 206-93.
16. Caporossi C, Cecconello I, Aguilar-Nascimento JE,Venço F, Gama-Rodrigues JJ. Hand-sewn and stapled esophageal anastomosis: experimental study in dogs. Acta Cir Bras. 2004, 19:319-27.

17. Dock DB, Latorraca MQ, Aguilar-Nascimento JE, Gomesda Silva, MH. Probiotics enhance recovery from malnutrition and lessen colonic mucosal atrophy after short-term fasting in rats. Nutrition. 2004; 20:473-6.

18. Ichikawa H, Kuroiwa T, Inagaki A, Shineha R, Nishihira. T.; Satomi, S.; Sakata, T.; Probiotic bacteria stimulate gut epithelial cell proliferation in rat. Dig Dis Sci 1999; 44:2119-23.

19. Pelto L, Isolauri E, Lilius EM, Nuutila J.Salminen S. Probiotic bacteria down-regulate the milk-induced inflammatory response in milk-hypersensitive subjects but have an immunostimulatory effect in healthy subjects. Clin Exp Allergy. 1998; 28:1474-9.

20. Rinne M, Kalliomaki M, Arvillomi H, Salminen S, Isolauri E. Effect of probiotics and breastfeeding on the bifidobacterium and Lactobacillus/ enterococcus microbiota and humoral immune responses $\mathrm{J}$ Pediatr. 2005; 147:186-91.

21. Malin M, Suomalainen H, Saxelin M, Isolauri E. Promotion of $\operatorname{IgA}$ immune response in patients with Crohn's disease by oral bacteriotherapy with Lactobacillus GG. Ann Nutr Metab. 1996; 40(3):137-45.

22. Madsen K. Probiotics and the immune response. J Clin Gastroenterol. 2006; 40:232-4.

23. Mangiante G, Colucci G, Gottin L, Casaril A, Ciola M, Facci E, Nicoli N. Influenza della somministrazione di probiotici nella guarigione delle anastomosi coliche. Chir Ital. 2001; 53(1):39-44.
Correspondência:

José Eduardo de Aguilar-Nascimento

Rua Estevão de Mendonça, 81 - Apto. 801

78045-200 - Cuiabá - MT - Brasil

e-mail: aguilar@terra.com.br
Conflito de interesses: nenhum Fonte de Financiamento: nenhuma

\section{How to cite this article:}

Aguilar-Nascimento JE, Prado S, Zaffani G, Salomão AB, Neves JS, Dock-Nascimento DB, Mello PRB, Okay TS. Perioperative administration of probiotics: effects on immune response, anastomotic resistance and colonic mucosal trophism. Acta Cir Bras. [serial on the Internet] 2006;21 Suppl 4. Available from URL: http:/www.scielo.br/acb. 